\title{
NILAI BUDAYA DALAM MASYARAKAT BANJAR ( KALIMANTAN SELATAN)
}

\author{
Endang Astuti \\ Email: 2010128220009@ulm.ac.id \\ Program Studi Pendidikan IPS Fakultas Keguruan dan Ilmu Pendidikan \\ Universitas Lambung Mangkurat \\ Banjarmasin
}

\begin{abstract}
Abstrak
Antropologi berarti ilmu pengetahuan tentang manusia di mana manusia itu dipelajari dari segi struktur dan sifat fisiknya dan proses-proses psikologisnya dalam kaitannya,dalam ruang dan waktu maka ilmu pengetahuan itu disebut dengan antropologi fisik akan tetapi bilamana fokus perhatian diarahkan pada cara manusia mengorganisasikan kehidupan dalam kelompok kelompoknya sehingga membentuk struktur sosial atau kekerabatan maka disiplin itu lazim disebut antropologi sosial.
\end{abstract}

\section{PENDAHULUAN}

Antropologi berarti ilmu pengetahuan tentang manusia di mana manusia itu dipelajari dari segi struktur serta watak fisiknya serta proses- proses psikologisnya dalam kaitannya, dalam ruang serta waktu hingga ilmu pengetahuan itu diucap dengan antropologi raga hendak namun bilamana fokus atensi ditunjukan pada metode manusia mengorganisasikan kehidupan dalam kelompok kelompoknya sehingga membentuk struktur sosial ataupun kekerabatan hingga disiplin itu umum diucap antropologi sosial. tetapi butuh kita perhatikan kalau sepanjang ini yang terkategori sosial merupakan sesuatu cabang dari etnologi yang berinduk pada antropologi budaya, namungambaran ini tidak butuh membingungkan uraian sebab ruang lingkup antropologi mencakup bidang- bidang yang luas yang bertabiat fisiologis ataupun ragawi, sosial, serta budaya. Ruang lingkup kajian antropologi ini memiliki cabang- cabang yang berdiri sendiri selaku sesuatu ilmu ialah itu kan teknologi sudah tumbuh jadi 3 bidang ilmu antropologi raga, arkeologi, serta antropologi budaya. Antropologi budaya ialah sesuatu cabang antropologi yang sangat pesat tumbuh di tengah pesatnya pergantian peradaban manusia dikala ini Dimana 
masalah ini jadi fokus atensi dalam antropologi budaya ialah menarangkan adanya jalinan timbal balik antara manusia dan kebudayaan pada suatu masa dan ruang tertentu. dan dimana kebudayaan yakni salah satunya sarana yang membolehkan manusia buat dapat hidup di sisi lain. Manusia menciptakan kebudayaan dengan mengenakan benak, yakni ilham ilham maupun gagasan yang bekerja dalam uraian seseorang.

\section{KEBUDAYAAN SUKU BANJAR}

Adat kebudayaan masyarakat Banjar berasal dari suku Dayak yang manaadat Dayak tadi sesuaikan dan keyakinan baru mereka yakni Islam, terdapat pula sebagian ciri khas yang bisa ditemui dari orang Banjar yakni yang dini mereka memiliki kemampuan dalam mengolah zona pasang surut karna kehidupan suku bangsa sangat utama kelompok Banjar Kuala dan batang banjir sangat dekat dengan sungai serta sebagai sarana transportasi, orang Banjar tingkatkan bermacam- berbagai jukung maupun perahu sesuai manfaatnya sehingga dapat memakai kondisi geografis Kalimantan Selatan yang memiliki banyak sungai dan sebaik dapat jadi, rata- rata selaku ahli dalam mengelola lahan pasang surut jadi kawasan pemukiman dan budidaya pertanian, setelah itu suku Banjar memiliki rumah tradisional yang mereka sendiri itu rumah Banjar di mana segala jenis rumah Banjar memiliki tipe ialah tipe bubungan besar di mana jalinan besar yang sangat dikenal sebagai suku ini, dan pula suku Banjar pula memiliki tradisi lisan yang dipengaruhi oleh budaya Melayu, Arab dan Cina tradisi lisan Banjar yang jadi kesenian ini berkembang pada abad ke- 18 di antara lain semacam Madihin dan lamut. Madihin yakni puisi rakyat anonim buat jenis hiburan yang di informasikan maupun tuliskan dalam bahasa Banjar dengan wujud raga dan mental tertentu yang disesuaikan dengan ke situ folklor Banjar kebalikannya lamut yakni tradisi berkisah yang berisi cerita tentang pecahan dan nilainilai keagamaan, sosial, serta budaya Banjar. kebudayaan yang lain ialah seni teater tradisional diucap Manda Manda hampir mirip dengan lenong hendak namun tokoh- tokoh yang dimainkan lebih bagus semacam raja, perdana menteri, panglima, permaisuri dan sebagainya.

\section{NILAI BUDAYA}

Nilai budaya merupakan suatu berkaitan dengan aktivitas masyarakat baik secara kelompok maupun individu. nilai yang muncul tersebut dapat bersifat positif apabila akan berakibat baik namun akan bersifat negatif jika berakibat buruk pada objek yang diberikan nilai. nilai budaya 
merupakan nilai yang ada dan berkembang di dalam masyarakat, nilai budaya ialah nilai yang terdapat serta tumbuh di dalam warga, nilai budaya itu merupakan tingkatan awal kebudayaan sempurna ataupun adat dimana nilai budaya ialah susunan sangat abstrak serta luas ruang lingkupnya. jadi nilai budaya merupakan sesuatu yang dikira sangat mempengaruhi serta dijadikan pegangan untuk sesuatu warga dalam memastikan seorang perikemanusiaan ataupun tidaknya. ada pula nilai- nilai budaya terdiri dari konsepsi- konsepsi yang hidup dalam alam benak sebagian besar warga menimpa hal- hal yang wajib mereka anggap sangat bernilai dalam hidup. oleh sebab itu sesuatu sistem nilai budaya umumnya berperan selaku pedoman paling tinggi untuk kelakuan manusia semacam sistem tata kelakuan manusia yang tingkatnya lebih konkrit semacam aturan- aturan spesial serta nilai- nilai budaya tersebut. Nilai Budaya Nasional pada dasarnya masih memerlukan pengkajian yang mendalam dan memerlukan penelitian lanjutan seperti apakah nilai budaya tersebut ketika berada di dalam kontek lokal atau nilai budaya lokal. Setidaknya terdapat 2 (dua) penelitian awal tentang Nilai Budaya Nasional yang pernah dilakukan di Indonesia, yaitu penelitian yang dilakukan oleh Hofstede (1983) dan penelitian yang dilakukan oleh Troompenaar (1997). Troompenaar membagi 5 orientasi hubungan yang mengarahkan pada cara-cara dimana oang menyesuaikan satu sama lainnya, serta 2 sikap yang mengarah pada waktu dan lingkungan.

\section{NILAI BUDAYA MASYARAKAT KALIMANTAN SELATAN ( BANJARMASIN)}

Indonesia mempunyai bermacam- macam kebudayaan yang di mana pula adat istiadat serta suku sampai agama dan bahasa keragaman tersebut ialah suatu yang sangat bermakna serta membagikan bahan kajian yang luas dan membagikan khasiat buat kehidupan warga sehingga bisa membangun bangsa serta meningkatkan dunia keilmuan. Salah satu profesi di Indonesia yang mempunyai kekhasan tertentu merupakan Kalimantan Selatan dimana Selatan ialah suatu profesi yang terletak di bagian tenggara pulau Kalimantan, serta Kalimantan Selatan memilikisuku terbanyak ialah suku Banjar di mana orang Banjar merupakan kelompok etnis terbanyak yang mendiami provinsi ini. Nilai lokal yang berkembang dalam sesuatu konteks budaya tertentu terbatas buat sesuatu kelompok warga tertentu dimana nilai tidak berdiri sendiri dalam keadaan vakum namun senantiasa terpaut dengan konteks kehidupan sekelompok orang serta dilanjutkan dipengaruhi oleh area alam, hawa, sosial- ekonomi, serta lain lain. Nilai- nilai lokal warga Banjar ialah nilai- nilai budaya yang hidup dalam masyarakatnya sehingga konsepsi- 
konsepsi itu semenjak lama sudah berakar dalam alam jiwa mereka, nilai- nilai warga Banjaryang khusus ataupun kas yang pastinya berbeda dengan nilai lokal budaya lain. Nilai lokal ini selaku pembeda yang dianut warga Banjar bisa menjadikan modal dalam menguasai serta menyikapi warga setempat yang bisa menjadikan keunggulan.

Orang Banjar dengan kebudayaannya memiliki faktor dominan nya dimana budaya merupakan emergen properti dari individu- individu yang berhubungan dengan mengelola serta mengganti area mereka, serta kebudayaan yang memiliki faktor dominan ialah dari segi bahasa yang mana bahasa Banjar serta dari segi keberagamannya ialah di mana merupakan Islam sebab normal bila budaya Banjar pula berkaitan dengan ikatan manusia dengan Tuhan yang mana budaya Banjar dalam ikatan manusia dengan sesamanya pula berkaitan dengan sistem kekerabatan serta perilaku keberagaman. Tiap warga tentu mempunyai ataupun hadapi pergantian di mana pergantian tersebut berlangsung lambat ataupun cepat serta mempengaruhi luas ataupun terbatas sebab orang Banjar pula terbuka terhadap pemikiran- pemikiran baru yang rasional serta tercantum gimana melaksanakan aktivitas secara lebih instan sehingga dengan penemuan nilai konsepsi dalam benglansar dada maksudnya biarpun wajib berani berselancar dadanya maknanya seorang wajib berjuang dengan serius.

\section{KESIMPULAN}

Adat kebudayaan warga Banjar berasal dari suku Dayak yang manaadat Dayak keharingan tadi sesuaikan serta kepercayaan baru mereka ialah Islam, ada pula sebagian karakteristik khas yang dapat ditemui dari orang Banjar ialah yang dini mereka mempunyai keahlian dalam mencerna zona pasang surut karna kehidupan suku bangsa sangat utama kelompok Banjar Kuala serta batang banjir sangat dekat dengan sungai dan selaku fasilitas transportasi, orang Banjar tingkatkan bermacam- bermacam jukung ataupun perahu cocok khasiatnya sehingga bisa mengenakan keadaan geografis Kalimantan Selatan yang mempunyai banyak sungai serta sebaik bisa jadi, rata- rata sebagai pakar dalam mengelola lahan pasang surut jadi kawasan pemukiman serta budidaya pertanian, sehabis itu suku Banjar mempunyai rumah tradisional yang mereka sendiri itu rumah Banjar di mana seluruh tipe rumah Banjar mempunyai jenis yakni jenis bubungan besar di mana jalinan besar yang sangat diketahui selaku suku ini, serta pula suku Banjar pula mempunyai tradisi lisan yang dipengaruhi oleh budaya Melayu, Arab serta Tiongkok 
tradisi lisan Banjar yang jadi kesenian ini tumbuh pada abad ke- 18 di antara lain semacam Madihin serta lamut.

\section{REFERENSI}

Mutiani, M. (2015). Pemanfaatan Puisi Sebagai Sumber Belajar Ips Untuk Menumbuhkan Kesadaran Lingkungan Peserta Didik Di SMP Negeri 6 Banjarmasin. Jurnal Pendidikan Ilmu Sosial, 24(2), 199-208.

Subiyakto, B., Abbas, E. W., Arisanty, D., Mutiani, M., \& Akmal, H. (2020). Sungai dan

Kehidupan Masyarakat Banjar: Penguatan Lokalitas dalam Wacana Pendidikan IPS yang Responsif.

Mutiani, M. (2018). Literasi Budaya Lokal Sebagai Wahana Edukasi Di Era Milenial.

Subiyakto, B., Abbas, E. W., Arisanty, D., Mutiani, M., \& Akmal, H. (2020). Sungai dan Kehidupan Masyarakat Banjar: Penguatan Lokalitas dalam Wacana Pendidikan IPS yang Responsif.

Yunus, R. (2013). Transformasi nilai-nilai budaya lokal sebagai upaya pembangunan karakter bangsa. Jurnal Penelitian Pendidikan, 13(1), 67-79.

Sati, A. L., Marhamah, M., Nurhot, N., \& Dewi, U. (2021). Representasi Nilai Pancasila Dalam Kehidupan Berbudaya. Jurnal Syntax Fusion, 1(2), 1-11.

Subiyakto, B., Syaharuddin, S., \& Rahman, G. (2017). Nilai-Nilai Gotong Royong Pada Tradisi Bahaul Dalam Masyarakat Banjar Di Desa Andhika Sebagai Sumber Pembelajaran IPS. Vidya Karya, 31(2).

Putro, H. P. N., \& Jumriani, J. (2020). KEHIDUPAN SOSIAL DAN EKONOMI MASYARAKAT BANTARAN SUNGAI A SEBAGAI SUMBER BELAJAR IPS.

Istiqomah, E., \& Setyobudihono, S. (2017). Nilai Budaya Masyarakat Banjar Kalimantan Selatan: Studi Indigenous. Jurnal Psikologi Teori dan Terapan, 5(1), 1-6. 